\title{
Calculation of Diagnostic Parameters of Advanced Serological and Molecular Tissue-Print Methods for Detection of Citrus tristeza virus: A Model for Other Plant Pathogens
}

\author{
E. Vidal, R. K. Yokomi, A. Moreno, E. Bertolini, and M. Cambra
}

\begin{abstract}
First, fourth, and fifth authors: Laboratorio de Virología e Inmunología, Centro de Protección Vegetal y Biotecnología, Instituto Valenciano de Investigaciones Agrarias, Ctra. Moncada-Náquera km 5, 46113 Moncada, Valencia, Spain; second author: San Joaquin Valley Agricultural Sciences Center, United States Department of Agriculture-Agricultural Research Service, 9611 S. Riverbend Avenue, Parlier, CA 93648; and third author: Departamento de Protección Vegetal, Instituto de Ciencias Agrarias, ICA-CSIC, c/ Serrano 115dpo, 28006 Madrid.
\end{abstract}

Accepted for publication 14 August 2011.

\begin{abstract}
Vidal, E., Yokomi, R. K., Moreno, A., Bertolini, E., and Cambra, M. 2012. Calculation of diagnostic parameters of advanced serological and molecular tissue-print methods for detection of Citrus tristeza virus: A model for other plant pathogens. Phytopathology 102:114-121.

Citrus tristeza virus (CTV) is one of the most important virus diseases that affect citrus. Control of CTV is achieved by grafting selected virusfree citrus scions onto CTV-tolerant or -resistant rootstocks. Quarantine and certification programs are essential for avoiding the entry and propagation of severe strains of CTV. Citrus nurseries in Spain and central California (United States) maintain zero-tolerance policies for CTV that require sensitive, specific, and reliable pathogen-detection methods. Tissue-print (TP) real-time reverse-transcriptase polymerase chain reaction (RT-PCR) assay was compared with the validated TP enzyme-linked immunosorbent assay (ELISA), using the CTV-specific monoclonal antibodies 3DF1 and 3CA5, for CTV detection. In total, 1,395 samples from healthy and CTV-infected nursery and mature tree plants were analyzed with both methods. The total agreement between

specificity, and likelihood ratios) were evaluated in a second test involving 658 Citrus macrophylla nursery plants. Mexican lime indexing was used to evaluate samples with discrepant results in the analysis. For TP-ELISA, a sensitivity of 0.8015 , a specificity of 0.9963 , and a positive and negative likelihood ratio of 216.42 and 0.199 , respectively, were estimated. For TP real-time RT-PCR, a sensitivity of 0.9820 , a specificity of 0.8519 , and a positive and negative likelihood ratio of 6.63 and 0.021 , respectively, were estimated. These diagnostic parameters show that TP real-time RT-PCR was the most sensitive technique, whereas TP-ELISA showed the highest specificity, validating the use of the molecular technique for routine CTV-detection purposes. In addition, our results show that the combination of both techniques can accurately substitute for the conventional biological Mexican lime index for the detection of CTV. The calculation of diagnostic parameters is discussed, as a necessary tool, to validate detection or diagnostic methods in plant pathology. Furthermore, assessment of the post-test probability of disease after a diagnostic result and CTV prevalence allows selection of the best method for accurate and reliable diagnosis.
\end{abstract} both detection methods was substantial (Cohen's kappa index of $0.77 \pm$ 0.03). The diagnostic parameters of each technique (i.e., the sensitivity,

Citrus tristeza virus (CTV), genus Closterovirus (21), has a high variability of isolates and is the causal agent of tristeza, one of the most important viral disease of citrus (25). The term tristeza refers to the bud-union or CTV-induced decline syndrome (slow or quick decline) of many citrus cultivars when grafted on sour orange (Citrus aurantium) rootstock. It has been estimated that more than 100 million sweet orange $(C$. sinensis $)$, mandarin (C. reticulata), and grapefruit (C. paradisi) trees on sour orange rootstock have been destroyed by CTV decline since 1930 (36). Although tristeza is predominantly a bud-union disease, the most aggressive CTV isolates, in addition to the decline syndrome on sour orange, induce other disorders, including stem pitting (SP), stunting, poor productivity, and impaired fruit quality of many commercial cultivars when grown on tristeza-tolerant rootstocks or in seedlings (9).

Historically, CTV has been introduced by humans into new regions when importing and using infected budwood to establish new orchards, followed by local spread by aphids in a semi-

Corresponding author: M. Cambra; E-mail address: mcambra@ivia.es

http://dx.doi.org/10.1094/PHYTO-05-11-0139

(c) 2012 The American Phytopathological Society
Additional keywords: Bayes' theorem, direct tissue blot immunoassay. persistent manner. The most efficient aphid vector of CTV is Toxoptera citricida (46). However, Aphis gossypii is a competent vector species when $T$. citricida is not present $(9,45)$.

Control of CTV in Spain and central California is based on the grafting of selected virus-free citrus scions onto CTV-tolerant or -resistant rootstocks. In addition, quarantine and certification programs are essential for avoiding importation and propagation of severe strains that cause SP in commercial varieties (25). Because there is zero tolerance for CTV in citrus nurseries in Spain and central California, it is critically important to use sensitive, specific, and reliable CTV detection methods to ensure the CTVfree status of nursery plants and to avoid the spread of CTV over long distances.

The traditional method for CTV detection is indexing by graftinoculation tests on Mexican lime seedlings ( $C$. aurantifolia) $(16,35)$. However, the disadvantages of high cost, time required (months) to confirm infection, and logistical difficulties make biological indexing impractical for the large-scale analyses required in eradication campaigns and in extensive certification programs (9). The development of an enzyme-linked immunosorbent assay (ELISA) for routine CTV diagnosis was a key advance because it permitted a much greater number of tests (18). The production of specific monoclonal antibodies against CTV 
$(7,28,34,42)$ greatly improved the specificity and sensitivity of ELISA procedures. A mixture of the monoclonal antibodies 3DF1 and 3CA5 (42) or their recombinant versions (41) allowed broadspectrum recognition of any CTV isolate $(8,9,16)$. The next important development was direct tissue-blot immunoassay (DTBIA) immunoprinting or tissue print (TP) to detect CTV $(11,19)$. The advantage of $\mathrm{TP}$ is that it does not require plantsample extraction, which is a laborious and time-consuming process, recommended by European and Mediterranean Plant Protection Organization (EPPO) protocol for CTV detection using 3DF1 and 3CA5 monoclonal antibodies (16). Reverse-transcriptase (RT) polymerase chain-reaction (PCR)-based methods have been developed, including an immunocapture phase (IC) (29), direct print-capture (33), and nested PCR in a single closed tube (31). Recently, real-time RT-PCR procedures have been developed $(3,37,39)$, improving the sensitivity of CTV diagnostic methods. Bertolini et al. (2008) (3) developed, based on Olmos et al. 1996 (33), a TP and squash real-time RT-PCR procedure using TaqMan chemistry to detect CTV in plant tissues and vectors without the use of extracts and nucleic acid purification. This procedure reduces the time and the cost of the analyses and is applicable in routine tests of a large number of samples but was not validated (23).

Numerous real-time PCR protocols for diagnosis of plant pathogens have been developed but they are rarely evaluated with respect to their reliability and reproducibility (32). Therefore, the objective of our work was to validate routine detection of CTV by the TP real-time RT-PCR procedure (3) in comparison with the standard reference technique of TP-ELISA using the validated monoclonal antibodies 3DF1 and 3CA5 (16). Samples with discrepant results in the analyses were tested by indexing on Mexican lime that was also evaluated.

The perfect diagnostic test with no false-positive or falsenegative results does not exist $(4,23)$. Therefore, the diagnostic parameters of a technique (sensitivity, specificity, and likelihood ratios [LRs]) must be calculated to characterize the efficacy of a diagnostic test (38). To correctly interpret the final result of any diagnostic test, information about the test's characteristics as well as its analyzed target (i.e., citrus plants in an orchard or a nursery) must be known (4). This information can be referenced to knowledge of the prevalence of the disease (pre-test probability), which is defined as the number of cases of a disease that are present in a particular population at a given time.

The factor that converts pre-test probability to post-test probability for a diagnostic test is the LR obtained using Bayes' theorem $(4,15)$. The positive LR will be used when sample diagnoses are positive and the negative LR will be applied when the diagnoses are negative. LRs are a useful tool in assessing the effectiveness of a diagnostic test (20). Therefore, the second aim of this work was to estimate the diagnostic parameters of both laboratory techniques to refine their practical use. Such estimators are very scarce in plant pathology $(23,32)$. However, their use is well known in medicine and veterinary disciplines before the use and commercialization of diagnostic tests and reagents. The advantages of advanced serological and molecular methods as well as the use of Mexican lime for accurate CTV detection are discussed.

\section{MATERIALS AND METHODS}

Plant material and experimental plots. In total, 1,395 samples, including adult trees and nursery plants, were included in the study in three different scenarios as follows: population (P) 1 included 149 mature lemon trees grafted on C. macrophylla grown in a screenhouse at Instituto Valenciano de Investigaciones Agrarias (IVIA) (Moncada, Valencia, Spain); P2 consisted of 20year-old sweet orange trees grafted on Carrizo citrange rootstock in two plots of 300 and 288 trees each in commercial fields in
Tulare County, CA (United States); and P3 was an experimental citrus nursery plot of $658 \mathrm{C}$. macrophylla plants established at IVIA (Moncada, Valencia Spain). Detection of CTV in the plants of the different populations by TP real-time RT-PCR was compared with that by TP-ELISA to determine the efficacy and validate TP real-time RT-PCR as a method for CTV diagnosis. The initial tests were performed in 2008: P1 in April, P2 in June, and P3 in December.

CTV monitoring. Two shoots per nursery plant or five shoots per mature tree must be collected for accurate detection of CTV $(10,16)$. Two imprints were made per shoot on nitrocellulose membranes and analyzed by TP-ELISA (11) using a commercial kit (Plant Print Diagnostics, Valencia, Spain) based on the mixture of the CTV-specific monoclonal antibodies 3DF1 and 3CA5 (42), following the manufacturer's protocol. The presence of a single precipitate focus located at the vascular area of the tissue-printed section of a shoot was enough to consider a tree to be CTV infected (11). Simultaneously, two fully expanded mature leaves on the same shoot were hand detached and their peduncles directly imprinted in a partially overlapping spot on a positively charged nylon membrane (Roche, Mannheim, Germany). The analysis of a shoot or two leaves from the same shoot has been reported as equally efficient for CTV detection (10). Pieces of membranes harboring the printed samples $\left(\approx 1.0 \mathrm{~cm}^{2}\right)$ were then processed for CTV detection by TP real-time RT-PCR (3).

Samples from 30 trees from the Tulare County plots were retested by both methods and indexed in Mexican lime (three replications with three inoculum pieces per source plant in July 2008) to ascertain their phytosanitary status. These included 7 trees with positive results obtained using TP-ELISA and negative results obtained using TP real-time RT-PCR, 12 plants with positive results obtained by TP real-time RT-PCR and negative results obtained by TP-ELISA, 7 plants with positive results from both techniques, and 4 plants with negative results from both techniques. The graft-inoculated Mexican lime plants were checked by visual inspection of symptoms 6 months postinoculation and tested by TP-ELISA.

Agreement between techniques. The agreement between techniques was evaluated using Cohen's kappa index (13), which indicates the proportion of agreement beyond that expected by chance. The benchmarks of Landis and Koch (22) were used to categorize Cohen's kappa index, where $<0.00$ is poor agreement, 0 to 0.2 is slight agreement, 0.21 to 0.40 is fair agreement, 0.41 to 0.60 is moderate agreement, 0.61 to 0.80 is substantial agreement, and 0.81 to 1.00 is almost perfect agreement. All data were also subjected to the McNemar $\chi^{2}$ test (24) to detect bias effect, which affects Cohen's kappa index results (17). If the McNemar $\chi^{2}$ test was significant, the data were adjusted using the Bias-Adjusted Kappa (BAK) index (6).

Calculation of diagnostic parameters. The plants tested in P3 with positive or negative diagnostic results were classified as true positives or true negatives if the same result was obtained by both laboratory tests: the serological TP-ELISA and the molecular TP real-time RT-PCR. Subsequently, they were pruned to a height of $20 \mathrm{~cm}$ and the plot was covered with an aphid-proof screen to avoid further natural infection of CTV by aphids in the spring. P3 plants with discordant results by both detection tests were retested in July 2009 to determine their true phytosanitary status. Samples were collected from new sprouts and tested by TP-ELISA and TP real-time RT-PCR, and they were indexed in Mexican lime plants. A result was considered to be accurate if at least two of the three performed tests had the same diagnostic result (16).

The sensitivity and specificity of the procedures were calculated (1) (Table 1). Sensitivity is the proportion of true positives that are correctly identified by a test, whereas the specificity is the proportion of true negatives that are correctly identified by the test. Confidence intervals (CI) $(95 \%)$ were estimated according to 
Wilson score method (44) with no continuity correction (27) using the formula:

$$
\frac{2 n p+z^{2} \pm z \sqrt{z^{2}+4 n p(1-p)}}{2\left(n+z^{2}\right)}
$$

where $p$ is the single proportion estimated, $z$ is the $1-\alpha / 2$ point of the standard normal distribution (i.e., 1.96 for CI [95\%]), $n$ is the size of population (for sensitivity, the number of true positives, and for specificity, the number of true negatives).

The LRs were estimated (15) (Table 1). The positive LR is the proportion of true positives correctly identified by the technique (sensitivity) divided by the proportion of false positive results that the method gives ( 1 - specificity). The negative LR is the proportion of false negatives given by the method ( 1 - sensitivity) divided by the proportion of true negatives correctly identified by the technique (specificity). CIs (95\%) were estimated (40) using the formula:

$$
L R(x)=\exp \left\{\ln \frac{p 1}{p 2} \pm z \sqrt{\frac{1-p 1}{p 1 n 1}+\frac{1-p 2}{p 2 n 2}}\right\}
$$

where, for positive LR, $p 1=$ sensitivity, $p 2=1$ - specificity, $p 1 n 1=$ true positives, and $p 2 n 2=$ false positives. When specifying the negative LR, $p 1=1-$ sensitivity, $p 2=$ specificity, $p 1 n 1=$ false negatives, and $p 2 n 2=$ true negatives.

TABLE 1. Diagnostic test parameters for a detection technique and contingency table for their assessment

\begin{tabular}{llll}
\hline & \multicolumn{3}{c}{ Phytosanitary status (true disease state) } \\
\cline { 2 - 4 } Test result & Infected & Healthy & Total \\
\hline+ & $a$ & $b$ & $a+b$ \\
- & $c$ & $d$ & $c+d$ \\
Total & $a+c$ & $b+d$ & $\ldots$ \\
\hline
\end{tabular}

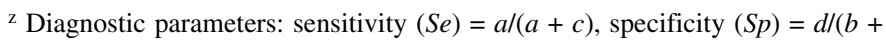
$d)$, LR $(+)=[S e /(1-S p)]=[a(b+d)] /[b(a+c)]$, and LR $(-)=[1-S e) / S p]=$ $[c(b+d)] /[d(a+c)]$, where $a=$ true positives, $b=$ false positives, $c=$ false negatives, $d=$ true negatives, and LR $=$ likelihood ratio.
The interpretation of the LRs of a diagnostic test was established (20) as follows: LRs of $>10$ or $<0.1$ indicate large and often conclusive changes from pre-test to post-test probability, LRs of 5 to 10 or 0.1 to 0.2 indicate moderate shifts in pre-test to post-test probability, LRs of 2 to 5 or 0.5 to 0.2 indicate small (but sometimes important) changes from pre-test to post-test probability, LRs of 1 to 2 or 0.5 to 1 indicate small (and rarely important) shifts from pre-test to post-test probability, and LR $=1$ indicates no change from pre-test to post-test probability.

A diagnostic test's post-test probability of infection for an individual plant after a diagnostic test result was calculated using Bayes' theorem (15), where pre-test probability = prevalence, pre-test odds $=$ prevalence $/(1-$ prevalence $)$, post-test odds $=$ pre-test odds $\times$ $\mathrm{LR}$, and post-test probability $=$ post-test odds $/(1+$ post-test odds $)$.

The LR of the combination of the two laboratory tests was estimated (26) as post-test odds $=$ pre-test odds $\times$ LR $1 \times$ LR 2 .

\section{RESULTS}

Agreement between techniques. The comparison of tested diagnostic procedures for CTV detection and resultant Cohen's kappa and BAK indices for agreement are shown in Table 2. Agreement among methods for P1 and P2 was almost perfect, with a Cohen's kappa index of 0.93 and 0.90 , respectively. In contrast, the agreement was categorized as substantial in $C$. macrophylla (P3), with a Cohen's kappa index of 0.63. However, the total percentage of coincidental results was $88.60 \%$, with Cohen's kappa and BAK indices of $0.77 \pm 0.03$.

Retested plants from Tulare plots. Results from 30 trees from the P2 plot in Tulare County that were resampled and retested by both serological and molecular methods based on the TP procedure and bio-indexed in Mexican lime are shown in Table 3. According to the EPPO protocol (16), out of 12 plants with positive results only by TP real-time RT-PCR, 2 were considered as true positives and 10 as false positives; 7 plants with only positive results by TP-ELISA were considered as true positives. In addition, 11 plants with coincidental results in June 2008 (7 positives and 4 negatives) had the same diagnostic result with the three detection methods of CTV.

TABLE 2. Comparison and agreement measures between tissue-print (TP) enzyme-linked immunosorbent assay (ELISA) and TP-real-time reverse-transcriptase polymerase chain reaction (RT-PCR) for the detection of Citrus tristeza virus in 1,395 citrus mature trees and citrus nursery plants

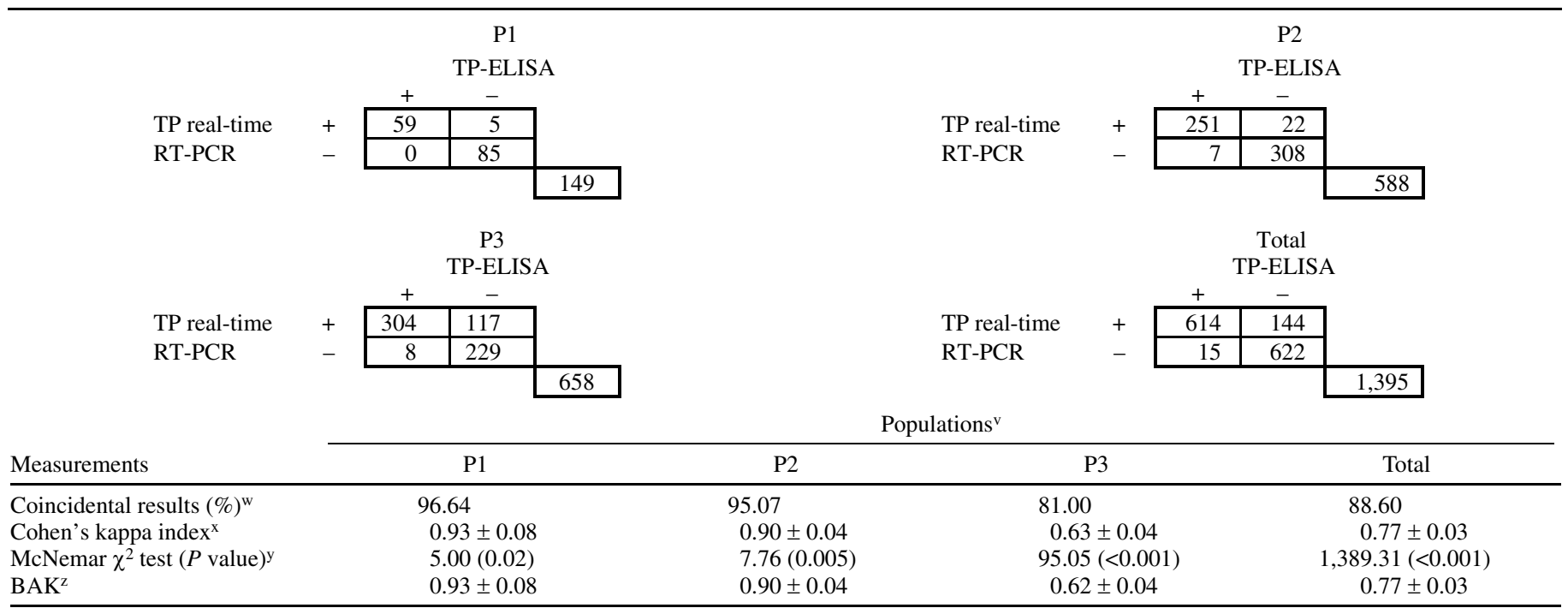

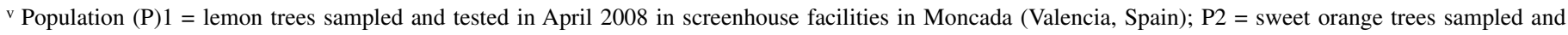
tested in June 2008 in Tulare County, CA (United States); P3 = Citrus macrophylla nursery plants sampled and tested in December 2008 in Moncada (Valencia, Spain); and Total $=$ summary of the diagnostic results obtained in the different populations.

${ }^{w}$ Percentage of plants with coincidental diagnostic results by both techniques divided per total number of analyzed plants.

x Cohen's kappa index \pm standard deviation.

y McNemar $\chi^{2}$ test $\left(P\right.$ value $<0.05$ indicates that McNemar $\chi^{2}$ test is significant $)$.

z Bias-Adjusted Kappa (BAK) index \pm standard deviation. 
Calculation of the diagnostic parameters. The CTV diagnostic results from the P3 experimental nursery plot are shown in Table 4. Of the 658 nursery plants analyzed, 125 had discrepant diagnostic results. Specifically, 117 tested negative with TPELISA but positive with TP real-time RT-PCR versus 8 plants that tested positive with TP-ELISA but negative with TP real-time RTPCR. When these 125 nursery plants with discordant diagnostic results were retested in July 2009 by both laboratory methods and compared with Mexican lime indexing (Table 4, lower panel), of the 117 plants that were positive only with TP real-time RT-PCR, only 77 were classified as true positives, with the remaining 40 plants classified as false positives. Of the eight $C$. macrophylla plants deemed a positive with TP-ELISA but negative with the PCR-based method, seven were classified as true positives in the July 2009 tests. These results were used to make the contingency tables (Table 5) for estimating the diagnostic parameters for both diagnostic techniques.

The estimated diagnostic parameters for sensitivity and specificity and their associated LR for TP-ELISA and TP real-time RTPCR in the nursery assay are shown in Table 6. These data show that the most sensitive technique was TP real-time RT-PCR, with a sensitivity of 0.9820 (CI 95\%: 0.9632 to 0.9912 ) versus 0.8015 (CI 95\%: 0.7590 to 0.8382 ) for TP-ELISA. In contrast, the most specific technique was TP-ELISA, with a specificity of 0.9963 (CI 95\%: 0.9793 to 0.9993 ) versus 0.8519 (CI 95\%: 0.8046 to 0.8893 ) for TP real-time RT-PCR. The positive LRs were 216.42 (CI 95\%: 30.58 to $1,531.81$ ) and 6.63 (CI 95\%: 4.98 to 8.83 ) for TP-ELISA and TP real-time RT-PCR, respectively. The negative
LRs were 0.199 (CI 95\%: 0.163 to 0.243 ) and 0.021 (CI 95\%: 0.010 to 0.044 ) for TP-ELISA and TP real-time RT-PCR, respectively.

The post-test probability of CTV infection of an individual plant, based on the prevalence of infection, after a diagnostic result of TP-ELISA, TP real-time RT-PCR, or both is shown in Figure 1. This figure illustrates the post-test probabilities of CTV detection as a function of the pre-test probabilities.

\section{DISCUSSION}

The overall capacity of TP-ELISA and TP real-time RT-PCR for detection of CTV in symptomless plants was excellent. Our results show a substantial agreement (22) (Cohen's kappa index of $0.77 \pm 0.03$ ) between the TP real-time RT-PCR method and the TP-ELISA technique, which is a validated and well-tested CTV diagnostic technique when the 3DF1 and 3CA5 monoclonal antibodies are used. This indicates the suitability of the molecular PCR-based technique for CTV diagnosis.

The McNemar $\chi^{2}$ test indicated that bias was significant for plants tested in the three different scenarios. Thus, significant differences were observed in the number of positive cases detected between both laboratory methods; these differences are a reflection of different sensitivities or specificities (47). However, Cohen's kappa index remained strong, because no differences between Cohen's kappa and BAK indices were observed, probably because the bias effect is only detected by Cohen's kappa index when there is a low level of agreement between techniques (6).

TABLE 3. Results of the detection of Citrus tristeza virus in 30 mature sweet orange trees from Tulare County plots ${ }^{\mathrm{Z}}$

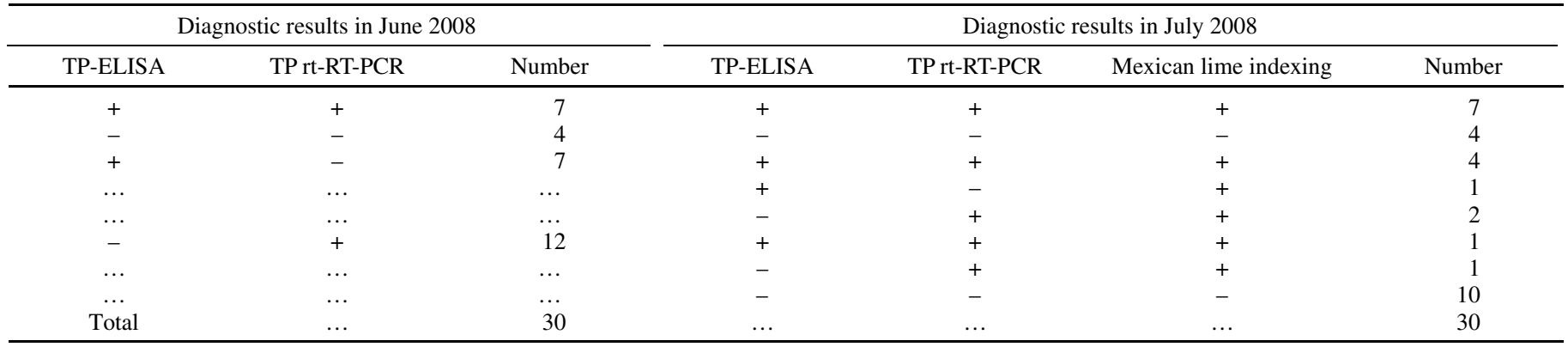

${ }^{\mathrm{z}}$ TP-ELISA $=$ tissue print-enzyme-linked immunosorbent assay (3DF1 and 3CA5 based), TP rt-RT-PCR $=$ TP real-time reverse-transcriptase polymerase chain reaction, and Number $=$ number of plants analyzed.

TABLE 4. Comparison of tissue-print (TP) enzyme-linked immunosorbent assay (ELISA) and TP-real-time reverse-transcriptase polymerase chain reaction (rtRT-PCR) for the detection of Citrus tristeza virus (CTV) in 658 Citrus macrophylla nursery plants in Moncada (Valencia, Spain) in December 2008 ${ }^{2}$

\begin{tabular}{ll|r|r|r} 
& \multicolumn{3}{c}{ December 2008 } \\
\cline { 3 - 4 } & \multicolumn{2}{c|}{ TP-ELISA } \\
TP real-time & + & \multicolumn{1}{c}{-} & \\
RT-PCR & + & 304 & 117 & \\
\hline 8 & 229 & \\
\hline & & & 658 \\
\hline
\end{tabular}

\begin{tabular}{|c|c|c|c|c|c|c|c|c|}
\hline \multicolumn{3}{|c|}{ Diagnostic results in December 2008} & \multicolumn{4}{|c|}{ Diagnostic results in July 2009} & \multicolumn{2}{|c|}{ Number of plants } \\
\hline TP-ELISA & TP rt-RT-PCR & Number & TP-ELISA & TP rt-RT-PCR & Mexican lime index & Number & $\mathrm{TP}$ & FP \\
\hline- & + & 117 & + & + & + & 72 & $\ldots$ & $\ldots$ \\
\hline$\ldots$ & $\cdots$ & $\ldots$ & + & + & - & 3 & $\ldots$ & $\ldots$ \\
\hline$\ldots$ & $\ldots$ & $\ldots$ & + & - & - & 2 & $\ldots$ & $\ldots$ \\
\hline$\ldots$ & $\ldots$ & $\ldots$ & - & + & - & 4 & $\ldots$ & $\ldots$ \\
\hline$\ldots$ & $\ldots$ & $\ldots$ & - & - & - & 34 & $\ldots$ & 40 \\
\hline
\end{tabular}

\footnotetext{
${ }^{\mathrm{z}}$ Resample and retest in July 2009 of 125 plants with discrepant CTV detection result in December 2008. Number = number of analyzed plants. Mexican lime
} indexing evaluated 6 months after the inoculation. $\mathrm{TP}=$ true positives and $\mathrm{FP}=$ false positives. 
However, there was less agreement between both laboratory techniques when testing C. macrophylla plants in a nursery plot, possibly due to a variety of factors, including host, season when tested, or both. The first samples from C. macrophylla were taken in winter when low temperatures were registered in Moncada (273 chilling hours $\left[<7^{\circ} \mathrm{C}\right]$ in December 2008). Because $C$. macrophylla is not a cold-hardy species, plant growth and development may have been deleteriously affected (14) and, consequently, reduced CTV replication and viral charge. Thus, the CTV titer was probably very low and detectable only by a very sensitive method such as TP real-time RT-PCR. Regardless, the total agreement between both techniques has been classified as substantial.

The high sensitivity estimates for TP real-time RT-PCR show that this method detected more true positives than TP-ELISA. The false positives obtained by the TP real-time RT-PCR technique could be due to recent infections with a low titer that were only detectable by the high sensitivity of the molecular test. These subclinical infections with a very low titer could have been subsequently eliminated by plant resistance mechanisms such as restriction of CTV infection to the inoculated area, impaired spread of the virus in the inoculated organ, restricted inter-organ movement of the virus, or systemic infection with a reduced virus titer (5). In addition, sap contamination when sampling could lead to unpredictable false positives that would only be detected by sensitive methods $(12,23,32)$. Another explanation for the false positives is that recent infections could have been eliminated by pruning of the nursery plants because the virus distribution is uneven in recently infected trees (10).

The high specificity for TP-ELISA confirms the high reliability of positives obtained by this serological method when using 3DF1 and 3CA5 monoclonal antibodies, as was previously reported (10). This agrees with results obtained from the Tulare plots, where all seven plants that only tested positive by TP-ELISA were classified as true positive when retested by both laboratory methods and by Mexican lime indexing, thus confirming the CTV infection previously detected by TP-ELISA.

Our results show the best accuracy for TP real-time RT-PCR in comparison with other validated molecular techniques. Cambra et al. (10) compared IC-RT-nested PCR with TP-ELISA for CTV detection in Clementine adult trees. Of the 111 plants analyzed, 12 showed discrepant diagnostic results, 6 plants with each technique. Posterior analysis using both laboratory methods and Mexican lime indexing showed that the six plants positive only with IC-RT-nested PCR were false positives, whereas five plants that were positive only with TP-ELISA were true positives, showing the high accuracy and specificity of the serological technique using the 3DF1 and 3CA5 monoclonal antibodies. Our results show that, of the 129 plants with positive diagnostic results detected only with TP real-time RT-PCR (12 plants, Table 3 and 117 plants, Table 4) and subsequently analyzed by TP-ELISA, TP real-time RT-PCR, and Mexican lime indexing, 79 plants were true positives (two plants, Table 3 and 77 plants, Table 4). Thus, TP real-time RT-PCR shows a higher reliability of positive results than IC-RT-nested PCR, which is a less sensitive CTV diagnostic technique than TP real-time RT-PCR (3).

It is also remarkable to note that, among 155 plants analyzed by the three different detection methods (biological, serological, and molecular), no CTV-infected plants were detected only by Mexican lime index (biological). This shows that the combination of the TP-ELISA and TP real-time RT-PCR can accurately substitute for conventional biological indexing in the detection of CTV.

A positive LR of 216.42 for TP-ELISA shows strong evidence for the assumption of disease with a positive test (20), while a

TABLE 6. Estimation of the diagnostic parameters of tissue-print (TP) enzyme-linked immunosorbent assay (ELISA) and TP-real-time reversetranscriptase polymerase chain reaction (rt-RT-PCR) for the detection of Citrus tristeza virus in routine analyses in citrus nursery blocks ${ }^{\mathrm{x}}$

\begin{tabular}{lc}
\hline $\mathrm{LR}^{\mathrm{y}}$ & Ratio $^{\mathrm{z}}$ \\
\hline $\mathrm{LR}_{1}+$ & $216.42(30.58-1,531.81)$ \\
$\mathrm{LR}_{1}-$ & $0.199(0.163-0.243)$ \\
$\mathrm{LR}_{2}+$ & $6.63(4.98-8.83)$ \\
$\mathrm{LR}_{2}-$ & $0.021(0.010-0.044)$ \\
$\mathrm{LR}++$ & $1,434.46(152.20-13,519.45)$ \\
$\mathrm{LR}+-$ & $4.58(0.31-67.71)$ \\
$\mathrm{LR}-+$ & $1.32(0.81-2.15)$ \\
$\mathrm{LR}--$ & $0.004(0.002-0.011)$ \\
\hline
\end{tabular}

${ }^{x}$ Parameter $(95 \%$ confidence interval): for TP-ELISA, sensitivity $=0.8015$ (0.7590 to 0.8382 ) and specificity $=0.9963$ (0.9793 to 0.9993$)$; for TP rt-RT$\mathrm{PCR}$, sensitivity $=0.9820(0.9632$ to 0.9912$)$ and specificity $=0.8519$ (0.8046 to 0.8893$)$.

y Likelihood ratios (LRs): $\mathrm{LR}_{1}+=$ positive $\mathrm{LR}$ for TP-ELISA; $\mathrm{LR}_{1}-=$ negative $\mathrm{LR}$ for TP-ELISA; $\mathrm{LR}_{2}+=$ positive $\mathrm{LR}$ for TP real-time RT-PCR; $\mathrm{LR}_{2}-=$ negative $\mathrm{LR}$ for TP real-time RT-PCR; LR $++=\mathrm{LR}$ for a plant with positive diagnostic results by both techniques; $\mathrm{LR}+-=\mathrm{LR}$ for a plant with positive diagnostic result by TP-ELISA and negative diagnostic result by TP real-time RT-PCR; LR- + = LR for a plant with a negative diagnostic result by TP-ELISA and positive diagnostic result by TP real-time RT-PCR; LR- - = LR for a plant with negative diagnostic results by both techniques.

${ }^{\mathrm{z}}$ Likelihood ratio (95\% confidence interval).

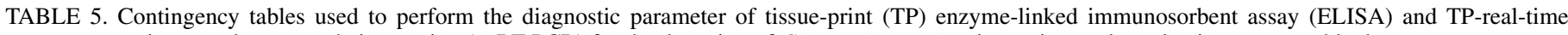
reverse-transcriptase polymerase chain reaction (rt-RT-PCR) for the detection of Citrus tristeza virus in routine analyses in citrus nursery blocks

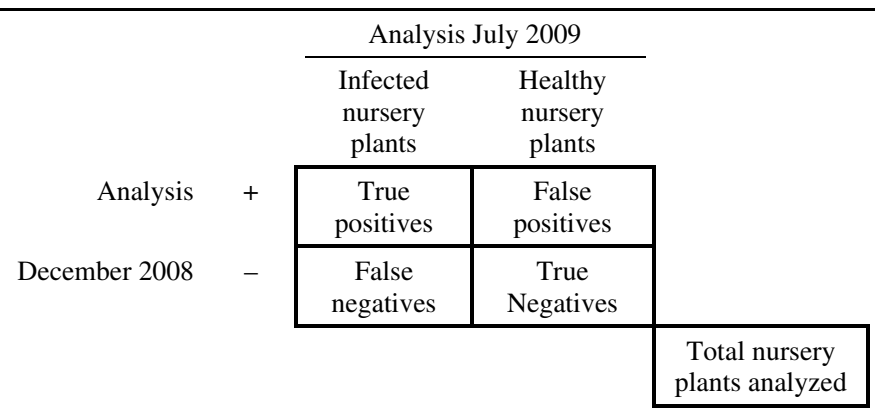

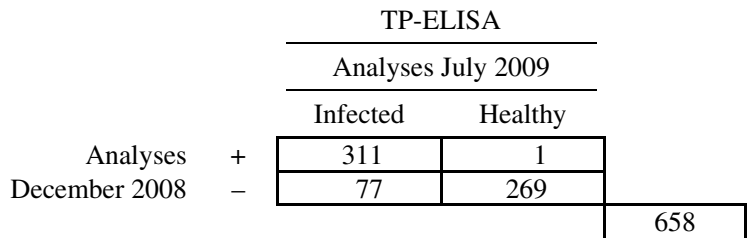

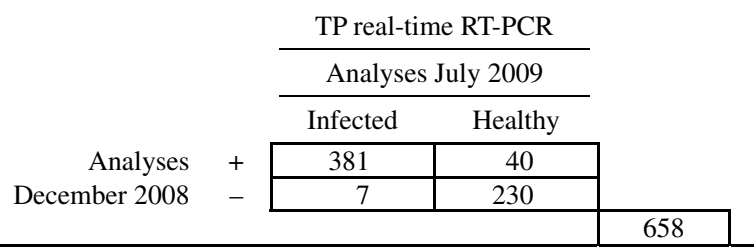


negative LR of 0.199 shows moderate evidence for ruling out the disease with a negative test. In contrast, for TP real-time RT-PCR, a positive LR of 6.63 indicates moderate evidence for the assumption of disease with a positive result, while a negative LR of 0.021 shows strong evidence to rule out disease with a negative result for CTV.

The estimated post-test probability value of CTV infection after a positive diagnostic result was higher for TP-ELISA than for TP real-time RT-PCR, with very low CTV prevalence $(0.01$ to $0.1 \%)$ due to the high positive LR (Fig. 1). However, the post-test probability value of CTV infection after a negative result was practically the same for both techniques. At the same time, with prevalence $>0.5 \%$, the post-test probability value of CTV infection for a negative test is lower for TP real-time RT-PCR than for TPELISA due to the lower negative LR. This difference increases with the prevalence and is higher than $1 \%$ only with a prevalence of $5 \%$ (Fig. 1). Similar results were reported for Plum pox virus (PPV) detection in adult trees $(12,30)$ and in nursery plants (43) when different diagnostic methods based on PCR procedures were compared with double-antibody sandwich-I-ELISA based on 5B-IVIA/AMR monoclonal antibody.

The estimated LRs can be used to choose the most appropriate diagnostic technique for a particular situation. If disease prevalence is low, as is usually the case in a citrus nursery, TP-ELISA is the most convenient technique for routine CTV assessment. However, when CTV-free status needs to be accurately assessed, it would be appropriate to include analysis by TP real-time RTPCR. In any event, testing by two methods provides the best accuracy and reliability of the testing results as recommended by the EPPO in different protocols for pathogen detection. Thus, the probability of infection of a nursery plant with a positive result obtained with two diagnostic methods is higher than the probability of infection of a nursery plant with a positive result obtained by only one diagnostic technique, even with low viral prevalence. Similarly, the accuracy of a negative result is very high when the analysis is performed by both laboratory techniques. Even with discrepant results between both techniques, the probability of infection of CTV exists. Therefore, analysis by

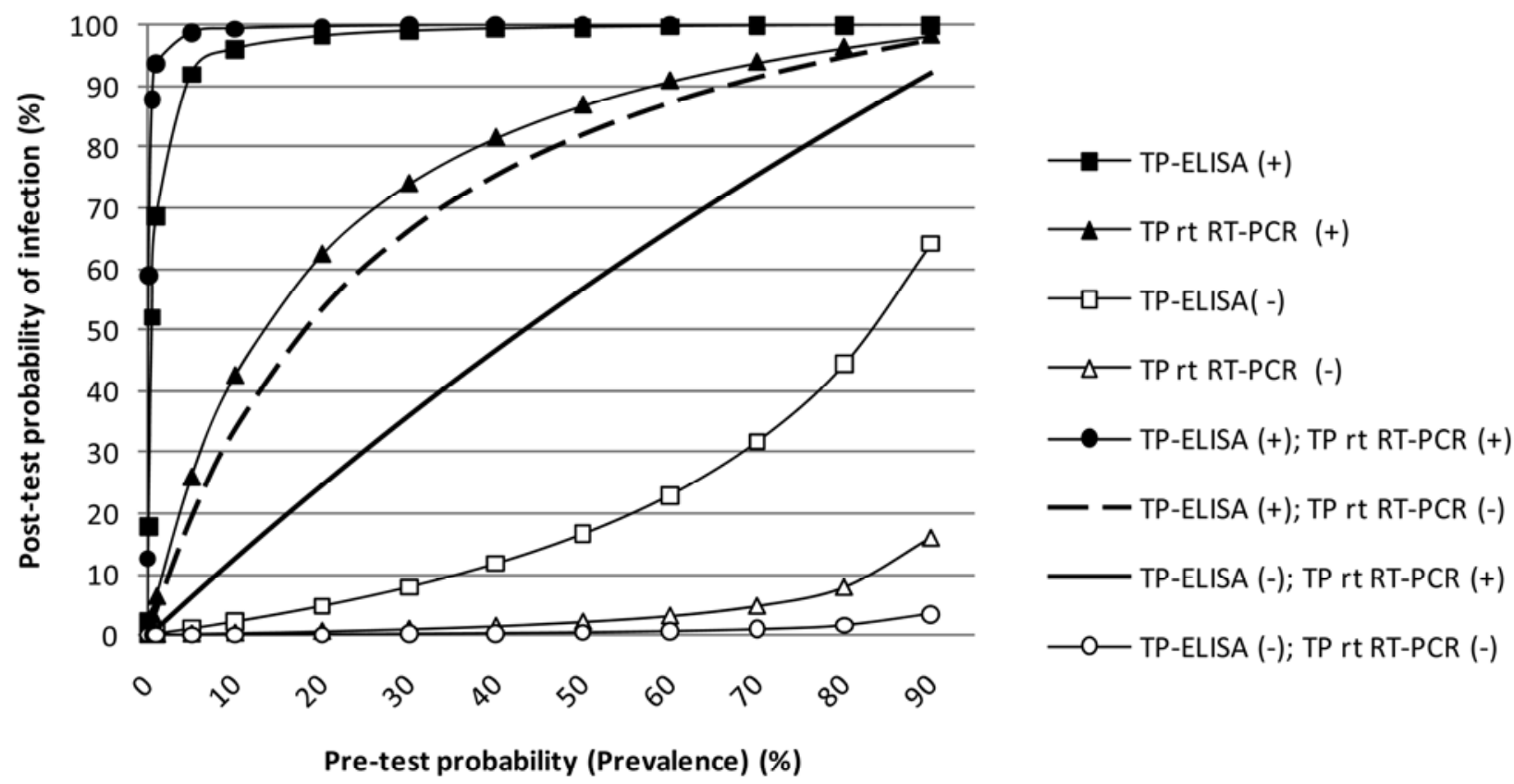

\begin{tabular}{|c|c|c|c|c|c|c|c|c|c|c|}
\hline Pre-test probability & $0.01 \%$ & $0.10 \%$ & $0.50 \%$ & $1.00 \%$ & $5.00 \%$ & $10.00 \%$ & $30.00 \%$ & $50.00 \%$ & $70.00 \%$ & $90.00 \%$ \\
\hline & \multicolumn{10}{|c|}{ Post-test probability of infection } \\
\hline \multicolumn{11}{|l|}{1 diagnostic method } \\
\hline TP-ELISA $^{\mathrm{a}}(+)^{\mathrm{b}}$ & $2.12 \%$ & $17.81 \%$ & $52.1 \%$ & $68.61 \%$ & $91.93 \%$ & $96.01 \%$ & $98.93 \%$ & $99.54 \%$ & $99.80 \%$ & $99.95 \%$ \\
\hline TP rt RT-PCR ${ }^{\mathrm{c}}(+)$ & $0.07 \%$ & $0.66 \%$ & $3.22 \%$ & $6.28 \%$ & $25.87 \%$ & $42.42 \%$ & $73.97 \%$ & $86.89 \%$ & $93.93 \%$ & $98.35 \%$ \\
\hline TP-ELISA (-) & $0.00 \%$ & $0.02 \%$ & $0.10 \%$ & $0.20 \%$ & $1.04 \%$ & $2.17 \%$ & $7.87 \%$ & $16.61 \%$ & $31.73 \%$ & $64.19 \%$ \\
\hline TP rt RT-PCR (-) & $0.00 \%$ & $0.00 \%$ & $0.01 \%$ & $0.02 \%$ & $0.11 \%$ & $0.24 \%$ & $0.90 \%$ & $2.08 \%$ & $4.71 \%$ & $16.02 \%$ \\
\hline \multicolumn{11}{|l|}{2 diagnostic method } \\
\hline TP-ELISA (+); TP rt RT-PCR (+) & $12.55 \%$ & $58.95 \%$ & $87.82 \%$ & $93.55 \%$ & $98.69 \%$ & $99.38 \%$ & $99.84 \%$ & $99.93 \%$ & $99.97 \%$ & $99.99 \%$ \\
\hline TP-ELISA (+); TP rt RT-PCR (-) & $0.05 \%$ & $0.46 \%$ & $2.25 \%$ & $4.43 \%$ & $19.45 \%$ & $33.77 \%$ & $66.29 \%$ & $82.10 \%$ & $91.46 \%$ & $97.64 \%$ \\
\hline TP-ELISA (-); TP rt RT-PCR (+) & $0.01 \%$ & $0.13 \%$ & $0.66 \%$ & $1.32 \%$ & $6.50 \%$ & $12.79 \%$ & $36.13 \%$ & $56.90 \%$ & $75.49 \%$ & $92.24 \%$ \\
\hline TP-ELISA (-); TP rt RT-PCR (-) & $0.00 \%$ & $0.00 \%$ & $0.00 \%$ & $0.00 \%$ & $0.02 \%$ & $0.04 \%$ & $0.17 \%$ & $0.40 \%$ & $0.92 \%$ & $3.47 \%$ \\
\hline
\end{tabular}

a Tissue print-ELISA

${ }^{\mathrm{b}}$ CTV-diagnostic result

${ }^{c}$ Tissue print real-time RT-PCR

Fig. 1. Relation between pre- and post-test probability of Citrus tristeza virus infection according to the results obtained by tissue-print enzyme-linked immunosorbent assay (TP-ELISA), TP real-time reverse-transcriptase polymerase chain reaction (rt RT-PCR), and the combination of both techniques. 
both techniques is recommended for cases with critical plant material such as bud-wood mother trees and plants for export, new introductions, and in quarantine facilities. Similar recommendations have been suggested for the management of PPV $(12,23,30)$ and have to be considered for the accurate detection of other plant pathogens.

These diagnostic tests can also be used in CTV eradication programs. The use of TP real-time RT-PCR would be the most appropriate for CTV prevalence $>5 \%$ because it produces fewer escapes of true positive plants. For disease prevalence $<5 \%$, TPELISA is preferred to maintain the infection levels as low as possible or until complete eradication is achieved. Related conclusions could issue for eradication purposes of other quarantine pathogens, showing the need to extend this kind of studies.

The high accuracy for positive TP-ELISA results has been confirmed, together with the validation of the real-time PCR as another potent technique for reliable and accurate detection of CTV. Furthermore, both techniques can substitute for biological indexing, especially if they are applied together. The cost and the time required for a test is much lower for laboratory techniques than for a biological indexing on Mexican lime, and large-scale analysis is only possible by both laboratory techniques, in spite of the efforts made in the past (2). In addition, our results demonstrate that a coincidental result obtained by both techniques leads to a practical accuracy of $100 \%$ to rule in or rule out the disease in an analyzed plant.

In conclusion, CTV detection by TP real-time RT-PCR can be used to monitor the sanitary status of commercial citrus trees and assist in the prevention of disease spread in nursery blocks. Furthermore, assessment of the post-test probability of CTV disease after a diagnostic result and CTV prevalence allows selection of the best method for accurate and reliable CTV diagnosis for any particular situation (e.g., eradication, quarantine, or certification program). This report constitutes the first validation using diagnostic parameters of TP-ELISA and TP real-time RT-PCR, two powerful detection techniques for CTV that use direct preparation of samples and avoid nucleic acid purification, thus facilitating routine CTV detection. The methodology used in this article could be applied to estimate the real accuracy of many reagents and detection methods of other plant pathogens, which are commonly used without validation. The selection of the most accurate detection method related to the prevalence of the pathogen is totally new in plant pathology, being essential for make decisions concerning the most appropriate detection procedure. Furthermore, the systematic use of validated procedures will increase the guarantee of phytosanitary passports and the success of eradication campaigns as well as the commercialization of pathogen-free plant material.

\section{ACKNOWLEDGMENTS}

This work was supported by grants from the Spanish Ministry of Science and Education (MEC, AGL2009-07531, and INIA RTA200500190) and Spanish Ministry of Environment and Rural and Marine Affaires, Subdirección Gral. de Sanidad de la Producción Primaria (Lab. Reference, IVIA 3101). The English version was revised by American Journal Experts. E. Vidal was recipient of a grant from the Spanish Instituto Nacional de Investigación y Tecnología Agraria y Alimentaria (INIA). We thank R. L. DeBorde, M. Krugner, and A. García (United States Department of Agriculture-Agricultural Research Service, Parlier, CA) and M. Gil, A. R. Corrales, M. C. Martínez, and M. T. Gorris (IVIA) for assistance in the collection of samples; and J. A. Pina (IVIA) for CTV indexing of Spanish samples on Mexican lime.

\section{LITERATURED CITED}

1. Altman, D. G., and Bland, J. M. 1994. Diagnostic tests 1: Sensitivity and specificity. BMJ 308:1552.

2. Bar-Joseph, M., Loebenstein, G., and Oren, Y. 1974. Use of Electron Microscopy in eradication of tristeza sources recently found in Israel.
Pages 83-85 in: Proc. 6th Conf. Int. Organ. Citrus Virol. L. G. Weathers and M. Cohen, eds. IOCV, Riverside, CA.

3. Bertolini, E., Moreno, A., Capote, N., Olmos, A., de Luis, A., Vidal, E., Pérez-Panadés, J., and Cambra, M. 2008. Quantitative detection of Citrus tristeza virus in plant tissues and single aphids by real-time RT-PCR. Eur. J. Plant Pathol. 120:177-188.

4. Bianchi, M. T., and Alexander, B. M. 2006. Evidence based diagnosis: Does the language reflect the theory? BMJ 333:442-445.

5. Bruening, G. 2006. Resistance to infection. Pages 211-240 in: Natural Resistance Mechanisms of Plants to Viruses. G. Loebenstein and J. P. Carr, eds. Springer, Dordrecht, The Netherlands.

6. Byrt, T., Bishop, J., and Carlin, J. B. 1993. Bias, prevalence and kappa. J. Clin. Epidemiol. 46:423-429.

7. Cambra, M., Camarasa, E., Gorris, M. T., Garnsey, S. M., Gumpf, D. J., and Tsai, M. C. 1993. Epitope diversity of citrus tristeza virus (CTV) isolates in Spain. Pages 33-38 in: Proc. 12th Conf. Int. Organ. Citrus Virol. P. Moreno, J. V. Da Graça, and L. W. Timmer, eds. IOCV, Riverside, CA.

8. Cambra, M., Garnsey, S. M., Permar, T. A., Henderson, C. T., Gumpf, D., and Vela, C. 1990. Detection of Citrus tristeza virus (CTV) with a mixture of monoclonal antibodies. (Abstr.) Phytopathology 80:1034.

9. Cambra, M., Gorris, M. T., Marroquín, C., Román, M. P., Olmos, A., Martínez, M. C., Hermoso de Mendoza, A., López, A., and Navarro, L. 2000. Incidence and epidemiology of Citrus tristeza virus in the Valencia Community of Spain. Virus Res. 71: 85-95.

10. Cambra, M., Gorris, M. T., Olmos, A., Martínez, M. C., Román, M. P., Bertolini, E., López A., and Carbonell E. A. 2002. European Diagnostic Protocols (DIAGPRO) for Citrus tristeza virus in adult trees. Pages 69-77 in: Proc. 15th Conf. Int. Organ. Citrus Virol. N. Durán-Vila, R. G. Milne, and J. V. da Graça, eds. IOCV, Riverside, CA.

11. Cambra, M., Gorris, M. T., Román, M. P., Terrada, E., Garnsey, S. M., Camarasa, E., Olmos, A., and Colomer, M. 2000. Routine detection of Citrus tristeza virus by direct Immunoprinting-ELISA method using specific monoclonal and recombinant antibodies. Pages 34-41 in: Proc. 14th Conf. Int. Organ. Citrus Virol. J. V. da Graça, R. F. Lee, and R. K. Yokomi, eds. IOCV, Riverside, CA.

12. Capote, N., Bertolini, E., Olmos, A., Vidal, E., Martínez, M. C., and Cambra, M. 2009. Direct simple preparation methods for the detection of Plum pox virus by real-time RT-PCR. Int. Microbiol. 12:1-6.

13. Cohen, J. 1960. A coefficient of agreement for nominal scales. Educ. Psychol. Meas. 20:37-46.

14. Davies, F., and Albrigo, L. G. 1994. Citrus. Crop Production Science in Horticulture Series, Volume 2. CAB International, Wallingford, UK.

15. Deeks, J. J., and Altman, D. G. 2004. Diagnostic tests 4: Likelihood ratios. BMJ 329:168-169.

16. EPPO. 2004. Diagnostic protocol for regulated pests. Citrus tristeza virus. Bull. OEPP/EPPO Bull. 34:239-246.

17. Feinstein, A. R., and Cicchetti, D. V. 1990. High agreement but low kappa: I. The problems with two paradoxes. J. Clin. Epidemiol. 43:543-549.

18. Garnsey, S. M., and Cambra, M. 1991. Enzyme-linked immunosorbent assay (ELISA) for citrus pathogens. Pages 193-216 in: Graft-Transmissible Diseases of Citrus. Handbook for Detection and Diagnosis. C. N. Roistacher, ed. FAO, Rome.

19. Garnsey, S. M., Permar, T. A., Cambra, M., and Henderson, C. T. 1993. Direct tissue blot immunoassay (DTBIA) for detection of Citrus tristeza virus (CTV). Pages 39-50 in: Proc. 12th Conf. Int. Organ. Citrus Virol. P. Moreno, J. V. da Graça, and L. W Timmer, eds. IOCV, Riverside, CA.

20. Jaeschke, R., Guyatt, G., and Lijmer, J. 2002. Diagnostic tests. Pages 121140 in: Users' Guides to the Medical Literature. G. Guyatt and D. Rennie, eds. AMA Press, Chicago.

21. Karasev, A. V., Boyko, V. P., Gowda, S., Nikolaeva, O. V., Hilf, M. E., Koonin, E. V., Niblett, C. L. Cline, K., Gumpf, D. J., Lee, R. F., Garnsey, S. M., Lewandowski, D. J., and Dawson, W. O. 1995.Complete sequence of the citrus tristeza virus RNA genome. Virology 208:511-520.

22. Landis, J. R., and Koch, G. G. 1977. The measurement of observer agreement for categorical data. Biometrics 33:159-174.

23. López, M. M., Llop, P., Olmos, A., Marco-Noales, E., Cambra, M., and Bertolini, E. 2009. Are molecular tools solving the challenges posed by detection of plant pathogenic bacteria and viruses? Curr. Issues Mol. Biol. 11:13-46.

24. McNemar, Q. 1947. Note on the sampling error of the difference between correlated proportions or percentages. Psychometrika 12:153-157.

25. Moreno, P., Ambrós, S., Martí-Albiach, M. R., Guerri, J., and Peña, L. 2008. Citrus tristeza virus: A pathogen that changed the course of the citrus industry. Mol. Plant Pathol. 9:251-268.

26. Neves, D. D., Dias, R. M., da Cunha, A. J., and Preza, P. C. 2004. What is the probability of a patient presenting a pleural effusion due to tuberculosis? Braz. J. Infect. Dis. 8:311-318.

27. Newcombe, R. G. 1998. Two-sided confident intervals for the single proportions: Comparison of seven methods. Stat. Med. 17:857-872. 
28. Nikolaeva, O. V., Karasev, A. V., Powell, C. A., Gumpf, D. J., Garnsey, S. M., and Lee, R. F. 1996. Mapping of epitopes for Citrus tristeza virusspecific monoclonal antibodies using bacterially expressed coat protein fragments. Phytopathology 86:974-979.

29. Nolasco, G., de Blas, C., Torres, V., and Ponz, F. 1993. A method combining immunocapture and PCR amplification in a microtiter plate for the routine diagnosis of plant viruses and subviral pathogens. J. Virol. Methods 45:201-218.

30. Olmos, A., Bertolini, E., Capote, N., and Cambra, M. 2008. An evidencebased approach to Plum Pox Virus detection by DASI-ELISA and RT-PCR in dormant period. Virol. Res. Treat. 1:1-8.

31. Olmos, A., Cambra, M., Esteban, O., Gorris, M. T., and Terrada, E. 1999. New device and method for capture, reverse transcription and nested PCR in a single closed tube. Nucleic Acids Res. 27:1564-1565.

32. Olmos A., Capote N., Bertolini E., and Cambra M. 2007. Molecular diagnostic methods for plant viruses. Pages 227-249 in: Biotechnology and Plant Disease Management. Z. K. Punja, S. De Boer, and H. I. Sanfaçon, eds. CABI Publishing, Wallingford, UK.

33. Olmos, A., Dasí, M. A., Candresse, T., and Cambra, M., 1996. Print capture PCR: A simple and highly sensitive method for the detection of plum pox virus (PPV) in plant tissues. Nucleic Acids Res. 24:2192-2193.

34. Permar, T. A., Garnsey, S. M., Gumpf, D. J., and Lee, R. F. 1990. A monoclonal antibody which discriminates strains of Citrus tristeza virus. Phytopathology 80:224-228.

35. Roistacher, C. N. 1991. Graft-Transmissible Diseases of Citrus. Handbook for Detection and Diagnosis. FAO, Rome.

36. Román, M. P., Cambra, M., Juárez, J., Moreno, P., Duran-Vila, N., Tanaka, F. A. O., Alves, E., Kitajima, E. W., Yamamoto, P. T., Bassanezi, R. B., Teixeira, D. C., Junior, W. C. J., Ayres, A. J., Gimenes-Fernandes, N., Rabenstein, F., Girotto, L. F., and Bové, J. M. 2004. Sudden death of citrus in Brazil: A graft-transmissible bud union disease. Plant Dis. 88:453-467.

37. Ruiz-Ruiz, S., Moreno, P., Guerri, J., and Ambrós, S. 2007. A real-time RT-PCR assay for detection and absolute quantitation of Citrus tristeza virus in different plant tissues. J. Virol. Methods 145:96-105.
38. Sackett, D. L., Haynes, R. B., Guyatt, G. H., and Tugwell, P. 1991. Clinical Epidemiology: A Basic Science for Clinical Medicine, 2nd ed. Little Brown, Boston.

39. Saponari, M., Keremane, M. L., and Yokomi, R. K. 2008. Quantitative detection of Citrus tristeza virus (CTV) in citrus and aphids by real-time reverse transcription-PCR (TaqMan). J. Virol. Methods 147:43-53.

40. Simel, D. L., Samsa, G. P., and Matchar, D. B. 1991. Likelihood ratios with confidence: Sample size estimation for diagnostic test studies. J. Clin. Epidemiol. 44:763-770.

41. Terrada, E., Kerschbaumer, R. J., Giunta, G., Galeffi, P., Himmler, G., and Cambra M. 2000. Fully "Recombinant enzyme-linked immunosorbent assays" using genetically engineered single-chain antibody fusion proteins for detection of Citrus tristeza virus. Phytopathology 90:13371344.

42. Vela, C., Cambra, M., Cortés, E., Moreno, P., Miguet, J., Pérez de San Román, C., and Sanz, A. 1986. Production and characterization of monoclonal antibodies specific for Citrus tristeza virus and their use for diagnosis. J. Gen. Virol. 67:91-96.

43. Vidal, E., Moreno, A., Bertolini, E., and Cambra, M. 2011. Estimation of the accuracy of two diagnostic methods for the detection of Plum pox virus in nursery blocks by latent class models. Plant Pathol. doi: 10.1111/j.1365-3059.2011.02505.x.

44. Wilson, E. B. 1927. Probable inference, the law of succession, and statistical inference. J. Am. Stat. Assoc. 22:209-212.

45. Yokomi, R. K., and DeBorde, R. L. 2005. Incidence, transmissibility and genotype analysis of Citrus tristeza virus (CTV) isolates from CTV eradicative and noneradicative districts in central California. Plant Dis. 89:859-866.

46. Yokomi, R. K., Lastra, R., Stoetzel, M. B., Damsteegt, V. D., Lee, R. F., Garnsey, S. M., Gottwald, T. R., Rocha-Peña, M. A., and Niblett, C. L. 1994. Establishment of the brown citrus aphid (Homoptera, Aphididae) in Central-America and the Caribbean Basin and transmission of Citrus tristeza virus. J. Econ. Entomol. 87:1078-1085.

47. Zhou, X. H. 1998. Correcting for verification bias in studies of a diagnostic test's accuracy. Stat. Methods Med. Res. 7:337-353. 